\title{
Macroinvertebrate assemblages of natural springs along an altitudinal gradient in the Bernese Alps, Switzerland
}

\author{
Fabian William Wigger*, Lara Schmidlin, Peter Nagel and Stefanie von Fumetti \\ 1 Biogeography Research Group, Department of Environmental Sciences, University of Basel, St. Johanns-Vorstadt 10, 4056 Basel, \\ Switzerland
}

Received 11 February 2015; Accepted 24 August 2015

\begin{abstract}
Alpine springs are sensitive ecotones which are inhabited by highly adapted organisms. Studies on how the species assemblages change vertically have not been conducted previously. We investigated 35 natural springs along an altitudinal gradient of about $2000 \mathrm{~m}$ in a valley in the Bernese Alps over 2 years. The aim of this study was to investigate the changes of the macroinvertebrate assemblages of natural springs along this gradient and to find out which environmental factors determine the distribution of the species along the altitudinal gradient. The spring fauna was quantitatively sampled three times and a wide range of environmental parameters were measured. The species richness significantly decreased with increasing altitude and the composition of the species assemblages changed distinctively along the altitudinal gradient. The low-elevation springs were dominated by crenobiont species, whereas high-altitude springs were mostly inhabited by taxa typical for Alpine headwaters in general. The mid-altitudinal range was a transition zone where crenobiont and alpine species co-existed. The water temperature was an important factor determining the species richness and the composition of macroinvertebrate assemblages of the springs at different altitudes. Moss, stones and the degree of forestation also had a significant influence on the composition of the macroinvertebrate assemblages. This study helps to understand the distribution of the spring fauna along altitudinal gradients. Knowing the current distribution ranges is an important prerequisite to predict potential changes of the species distribution, caused by global change, in the future.
\end{abstract}

Key words: Macroinvertebrate assemblages / alpine springs / water temperature / climate change

\section{Introduction}

Alpine springs are usually small but complex and species-rich ecotones (Cantonati et al., 2006; Gerecke and Franz, 2006). They often exhibit a mosaic-like substrate composition and a high degree of individuality regarding their macroinvertebrate assemblages (Cantonati et al., 2006). Crenobiont macroinvertebrate species exclusively occur in springs, while crenophiles favour springs, but can also be found in springbrooks (Cantonati et al., 2006). Surveys in the German and Italian Alps (Cantonati and Ortler, 1998; Gerecke and Franz, 2006; Sambugar et al., 2006; Bottazzi et al., 2011) and the French Pyrénéés (Brown et al., 2007) demonstrated a high $\alpha$ - and $\beta$-diversity for Alpine springs. This is caused by spatial and temporal hydro-ecological heterogeneity (Lassen and Savoia, 2005). Glacially fed rivers on the same altitude

\footnotetext{
*Correspondence author: f.wigger@unibas.ch
}

are dominated by snowmelt and glacial meltwater. The macroinvertebrate assemblages of those rivers differ strongly from those of groundwater-fed springs (Brown et al., 2003; Hannah et al., 2007). Due to their isolation and spatial fragmentation, springs are particularly vulnerable to changing environmental conditions (Woodward et al., 2010). Crenobiont species are potentially endangered by impacts of climatic changes, especially if they have a restricted distribution area (Hering et al., 2009). Until now, studies referring to climatic changes in the context of freshwaters either concentrate on single species (Taubmann et al., 2011), a species group (Altermatt et al., 2014) or focus on general aquatic ecosystems (Daufresne et al., 2007; Khamis et al., 2013).

Some studies investigating at the macroinvertebrate species composition along altitudinal gradients in aquatic systems exist (Burgherr and Ward, 2001; HenriquesOliveira and Nessimian, 2010; Obertegger et al., 2010), but until now no studies have been conducted in springs and springbrooks. As crenobionts are usually thought to 
be cold-water adapted species, a high occurrence of crenobionts in high Alpine, cold-water springs can be assumed. It is, however, still unclear whether or how the composition of the macroinvertebrate assemblages of springs changes along altitudinal gradients. One of the reasons may be owing to the lack of fine-grained faunistic data and information on the thermal preferences of the species (Hering et al., 2009). In our study, we investigated natural springs along an altitudinal gradient of about $2000 \mathrm{~m}$ in a valley in the Bernese Alps. The aim of the study was to investigate the macroinvertebrate assemblages and corresponding environmental parameters of natural springs at different altitudes. We had two leading questions, namely: (1) Does the faunistic composition significantly change along the altitudinal gradient? (2) Is the water temperature the driving environmental factor for this potential change? Possible consequences of climatic changes for springs and their inhabitants in Alpine regions are then discussed.

\section{Methods}

\section{Field investigations}

Thirty-five springs were located with the help of topographic maps and a direct search in the field in summer and autumn 2010 (Fig. 1) (Table 1). Subsequently we mapped suitable springs, i.e., natural springs and their surroundings. The mapping of the springs was conducted with an evaluation sheet developed for springs in Bavaria, Germany (Hotzy and Römheld, 2008). This comprises, for example, the substrate composition of the springs, anthropogenic impacts such as cattle trampling or water withdrawal and mapping of the surrounding vegetation. The substrate composition was determined by visually estimating the percentage of coverage of each substrate present within the first $5 \mathrm{~m}$ of the outflow. The percentage of coverage was categorized into three intensity classes given in the evaluation sheet: $0=0 \%$ coverage; $1=1-10 \%$ coverage; $2=10-50 \%$ coverage; $3 \geq 50 \%$ coverage. As the focus of the study was on natural springs, the anthropogenic impacts were low and we only classified if they were present $(=1)$ or not $(=0)$. The vegetation in the surrounding perimeter of approximately $5 \mathrm{~m}$ around the outflow of the spring was mapped. The percentage of coverage of conifers, deciduous forest and grassland was determined $(0=0 \%$ coverage; $1=1-10 \%$ coverage; $2=10-50 \%$ coverage; $3 \geq 50 \%$ coverage) and from that the total forest coverage around the spring was assessed. Moreover, the vascular plants were determined to species level within $1 \mathrm{~m}$ around the springs (Lauber and Wagner, 2001). Mosses and not flowering grasses were disregarded. Summer and winter shading were assessed photographically by taking a photograph of the sky above the spring. The percentage of shading was assessed and categorized as follows: $0=0 \%$ shading; $1=1-10 \%$ shading; $2=10-50 \%$ shading; $3 \geq 50 \%$ shading (Table 2 ).
Water temperature $\left({ }^{\circ} \mathrm{C}\right)$, oxygen concentration and saturation (mg.L $\mathrm{L}^{-1}$ and $\%$, respectively), $\mathrm{pH}$ and conductivity $\left(\mu \mathrm{S} . \mathrm{cm}^{-1}\right)$ were measured in the field using a Multi-Parameter Water Quality Meter (WissenschaftlichTechnische Werkstätten GmbH, Weilheim, WTW 3500i). Discharge was determined by measuring the amount of water entering a plastic bag in $5 \mathrm{~s}$ (Zollhöfer, 1997). The discharge of the investigated springs was classified in three levels: $1<0.5,2=0.5-2$ and $3>2$ L.s $^{-1}$.

The nutrient parameters phosphate $\left(\mathrm{PO}_{4}^{3-}\right)$, ammonia $\left(\mathrm{NH}_{4}^{+}\right)$and nitrate $\left(\mathrm{NO}_{3}^{-}\right)$were analyzed in the field with a portable photometer (MERCK Spectroquant NOVA 60).

The macroinvertebrates of all springs were quantitatively sampled in spring 2011, autumn 2011 and summer 2012 with a small Surber sampler $\left(0.01 \mathrm{~m}^{2}, 500 \mu \mathrm{m}\right.$ mesh width). At each sampling occasion four samples were taken proportionally to the main substrate types in the first $5 \mathrm{~m}$ after the outflow (von Fumetti et al., 2007). Samples were taken by gently shoveling the substrate within the $10 \times 10 \mathrm{~cm}$-frame of the surber sampler into the net of the sampler. After flushing the samples into a white dish the samples were washed with spring water and immediately preserved in $70 \%$ ethanol (von Fumetti et al., 2006). In the laboratory, they were sorted and the organisms were identified to the most precise taxonomic level possible (e.g., Aubert, 1959; Schmedtje and Kohmann, 1988; Studemann et al., 1992; Tachet, 2000; Glöer, 2002; Waringer and Graf, 2011; Lubini et al., 2012).

\section{Data processing and analysis}

All of the investigated springs were categorized into three altitudinal classes: lowland springs from 500 to $1600 \mathrm{~m}$ a.s.1., intermediate springs from 1600 to $1950 \mathrm{~m}$ a.s.l. and high Alpine springs above $1950 \mathrm{~m}$ a.s.l. The intermediate level is the transition zone where the treeline is located. It separates the lower zone, dominated by dense mixed forest, from the higher zone, dominated by open meadows with few single conifers and shrubs.

The faunistic data of the four samples we took from each spring, on each sampling occasion, were pooled. The three seasonal samples were subsequently also pooled. The final data set thus consisted of one data point per spring, originally derived from 12 single samples.

We performed a linear correlation analysis with the abiotic parameters, the number of macroinvertebrate taxa and the number of macroinvertebrate individuals as a function of altitude in PAST 2.09 (PAleontological STatistcs Version 2.09, Hammer, 2011).

Combined environmental and macroinvertebrate assemblages data were analyzed using Canonical Correspondence Analysis (CCA) with CANOCO 5.0 (ter Braak and Šmilauer, 1998). The distance of the species dissimilarity is measured by their chi-square. All species data were $(\log e+1)$-transformed prior to analyses, which were performed with a forward selection of explanatory variables. 


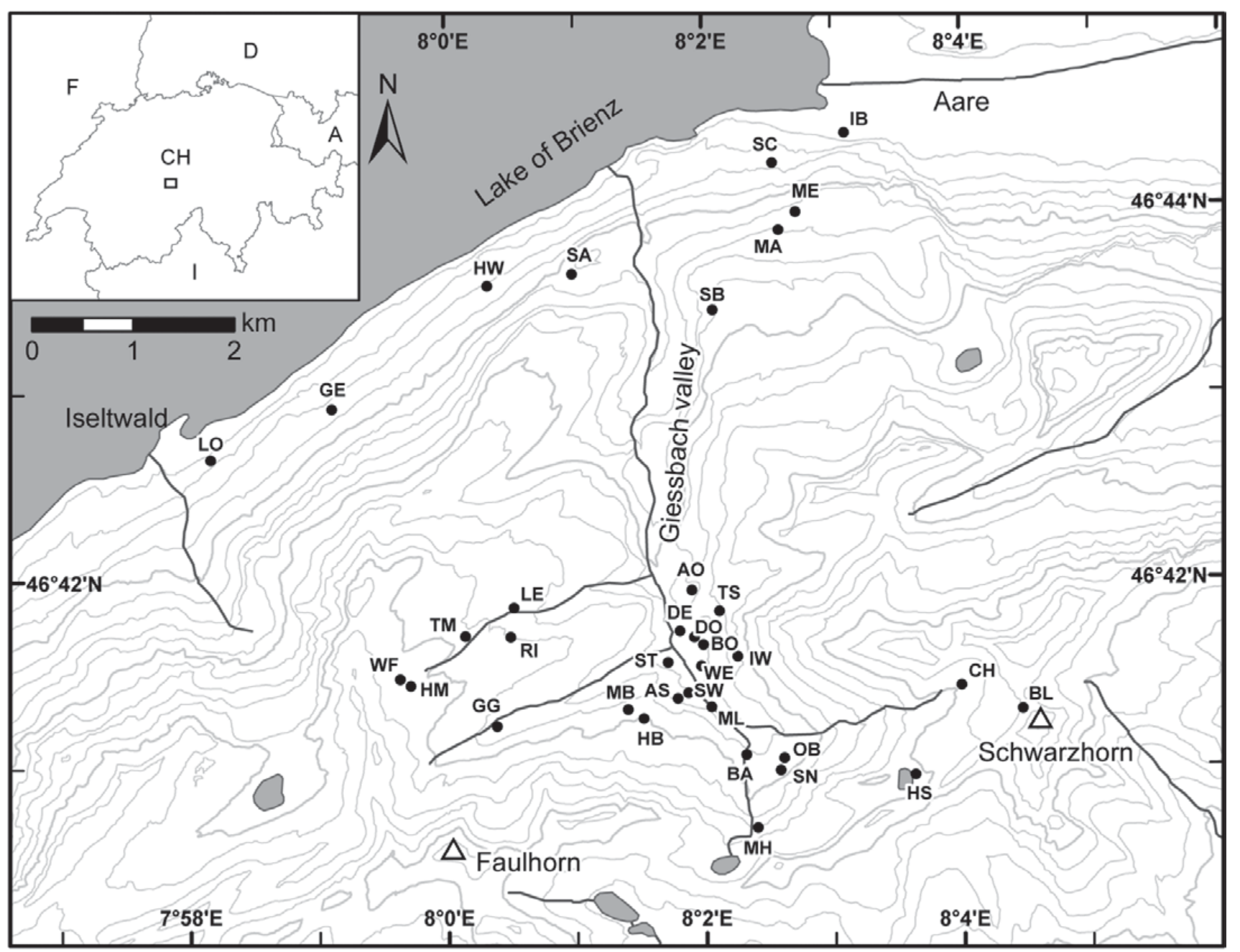

Fig. 1. Map of the investigation area in the Bernese Alps (Switzerland). $\bullet=$ spring sites; $100 \mathrm{~m}$ isolines, based on DHM25 (Swisstopo).

All further statistical analyses described below were calculated using PRIMER 6.0 (Clarke and Gorley, 2006). Ordination of the springs, based on the faunistic data, was conducted using non-metric multi-dimensional scaling (nMDS). An analysis of similarities-procedure (ANOSIM), which is analogous to an ANOVA, but relies on a similarity matrix and makes few assumptions on data, was used for testing the grouping of the springs. The similarity matrix was calculated from $\log e(x+1)-$ transformed abundance data, using the Bray-Curtis similarity index. We tested for differences of the macroinvertebrate assemblages among the three altitudinal zones. The Global Test gives the overall observed $\mathrm{R}$ statistic, whereas the pairwise test directly compares rank dissimilarities between and within two groups (Clarke and Gorley, 2006).

We subsequently ran a Similarity Percentages (SIMPER) analysis to assess dissimilarities between and similarities within altitudinal zones, and to identify the taxa that discriminate between the zones. The lower the similarity within groups and the higher the dissimilarity between groups is, the higher the $\beta$-diversity is.

\section{Results}

\section{Environmental parameters}

The $\mathrm{pH}$ of the springs ranged from 7.3 (spring BA) and 8.9 (spring ML) and the oxygen saturation ranged from $49 \%$ (springs $\mathrm{MH}$ and $\mathrm{TM}$ ) to $95 \%$ (spring ME). The conductivity ranged from $18 \mu{\mathrm{S} . \mathrm{cm}^{-1}}^{-1}$ (spring $\mathrm{MH}$ ) to $519 \mu \mathrm{S} . \mathrm{cm}^{-1}$ (spring MA). The number of vascular plants was highest around the spring SA at $1050 \mathrm{~m}$ a.s.l. At some springs above $1950 \mathrm{~m}$ a.s.l. no vascular plants were present around the springs (Table 1).

The linear correlation analysis revealed an inverse correlation of water temperature with altitude $(r,-0.760$; $P, 0.0001)$. The springs at the intermediate altitudinal range situated around the treeline showed a higher heterogeneity of water temperature.

The linear correlation analysis of vascular plant diversity and altitude showed a significant inverse correlation $(r,-0.533 ; P, 0.001)$. Likewise, conductivity also significantly decreased with altitude $(r,-0.517$; $P, 0.002)$. 


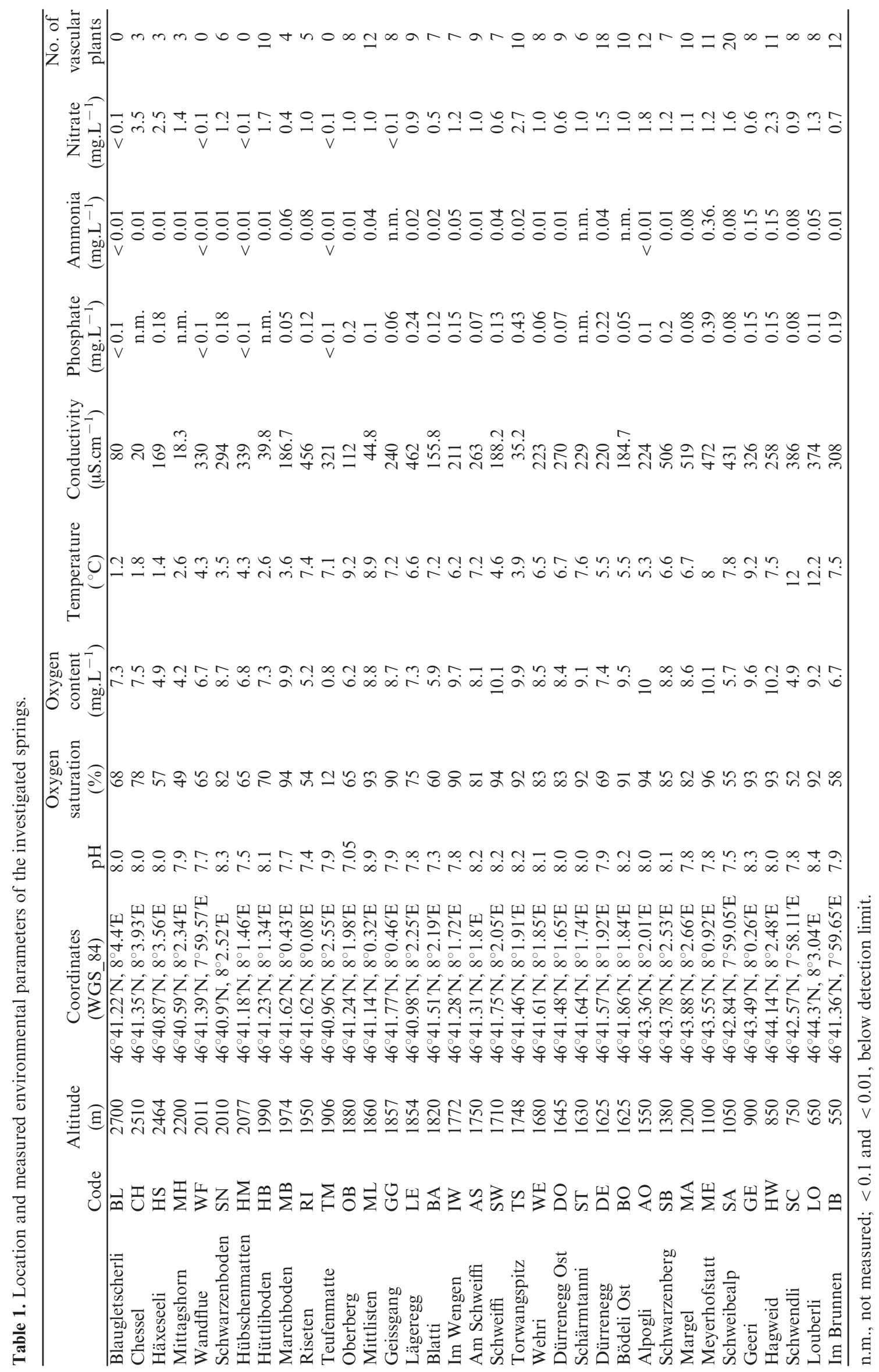




\section{Species richness}

A total of 114 species and higher taxa were found in the 35 investigated springs (Supplementary material). The number of taxa ranged between 4 in the highest elevated spring BL (2700 $\mathrm{m}$ a.s.1.) and 32 in the spring SW (1710 $\mathrm{m}$ a.s.l.) (mean \pm SD: $20.2 \pm 7$ ). The number of individuals found in each spring was highest in the spring MH at $2200 \mathrm{~m}$ a.s.l. with 1963 individuals and lowest in $\mathrm{BL}$ at 2700 m.a.s.l. with 24 individuals (mean $\pm \mathrm{SD}$ : $527 \pm 419$ ). Generally, Chironomidae was the most abundant taxon in all springs and especially in spring $\mathrm{MH}$.

Overall, the number of taxa was highest at the lowest altitudinal level up to $1400 \mathrm{~m}$ a.s.l. and lowest in the high Alpine springs above $1950 \mathrm{~m}$ a.s.l. The number of taxa showed a significant correlation with altitude $(r,-0.402$; $P, 0.018)$. The number of individuals did not show a significant correlation with altitude $(r, 0.170 ; P, 0.341)$, although we observed a slight increase with altitude.

The lowest springs situated between 500 and $1600 \mathrm{~m}$ a.s.l. were characterized by crenobiont taxa such as the trichopterans Crunoecia irrorata (Curtis, 1834), Beraea maurus (Curtis, 1834) and the gastropod Bythinella sp. Moreover, some crenobiont water mites were only present in these lowest springs. For example, Sperchon squamosus Kramer, 1879 only occurred in the springs ME (1100 m a.s.1.) and SC (750 $\mathrm{m}$ a.s.1.) and Protzia squamosa Walter, 1908 only occurred in the spring GE at $900 \mathrm{~m}$ a.s.l.

The springs located above $1900 \mathrm{~m}$ a.s.1. were inhabited by many Alpine species not restricted to springs. For example, Consorophylax consors (McLachlan, 1880), Drusus biguttatus (Pictet, 1834) and Rhyacophila intermedia McLachlan, 1868 were most abundant in high Alpine springs. The highest abundance of Chironomidae was found in the highest elevation springs.

The intermediate altitudinal zone can be considered as a transition zone, where typical crenobiont species, e.g., Beraea pullata (Curtis, 1834), and high Alpine species, e.g., Drusus discolor (Rambur, 1842), co-exist. At the intermediate altitude species richness of the water mites was highest. Some species such as Lebertia schechteli Thor, 1914 occurred from $1600 \mathrm{~m}$ a.s.l. upwards, whereas others such as Sperchon longirostris Koenike, 1895 occurred exclusively at the intermediate altitude.

The nMDS-plot, based on the faunistic data, revealed a clear separation of the altitudinal classes in assemblages' composition (Fig. 2). The corresponding ANOSIM significantly separated the three altitudinal ranges (Global $R$, $0.47 ; P, 0.001)$. The pairwise test showed that the species assemblages of springs at high and low altitudes, as well as of springs at intermediate and high altitudes differed, significantly $(R, 0.557 ; P, 0.001 ; \mathrm{R}: 0.544, P: 0.001$, respectively). Low and intermediate springs were less clearly, but still significantly, separated $(R, 0.324 ; P$, 0.002 ).

In the SIMPER analysis group 1 (high springs) had an average similarity of $26 \%$, group 2 (intermediate springs) of $42 \%$ and group 3 (low springs) of $26 \%$. The $\beta$-diversity was therefore lowest in the intermediate springs. The average dissimilarity scored $69 \%$ between groups 1 and 2 , $79 \%$ between groups 1 and 3, and $84 \%$ between groups 2 and 3 , indicating a high $\beta$-diversity along the altitudinal gradient. Generally all groups were dominated by Chironomidae.

\section{Relationship between species and environmental variables}

All environmental variables together explained $71.9 \%$ of the variance (the adjusted explained variation is $20.3 \%$ ) in the CCA. The significant explanatory variables accounted for $32.9 \%$ of the variance. The first four canonical axes explained $28.4 \%$ of the species variation (the explained fitted variation is $39.6 \%$; Table 3 ). On all axes the permutation test was significant (pseudo- $F$, 1.4; $P, 0.002)$. The CCA clearly separated three groups of springs primarily based on the variation in temperature, moss availability and altitude. Furthermore, the amount of stones, the degree of forestation and the ammonia content had a significant explanatory power (Fig. 3(a)). These three groups more or less represent the three altitudinal levels, with the lowest springs being influenced mainly by forestation, high ammonia contents and the water temperature. The springs at high altitudes were dominated by moss.

The taxon biplot identified the taxa associated with the three springs' groups (Fig. 3(b)). For example, the caddisfly $C$. irrorata, the amphipod Gammarus fossarum Koch, 1836 and certain water mite species only occurred in the forested springs. The limnephilid caddisflies $D$. biguttatus and $C$. consors were only present in the high Alpine springs dominated by moss. The Stratiomyidae Oxycera morrisii Curtis, 1833 and Beris vallata (Forster, 1771), and the stonefly Nemoura mortoni Ris, 1902 were present in the third group of springs around the forest located at the intermediate altitude between 1600 and $1950 \mathrm{~m}$ a.s.l.

\section{Discussion}

The composition of species assemblages clearly changed along the altitudinal gradient with characteristic species assemblages in each altitudinal zone. We recorded a significant decrease of species richness with increasing altitude.

Springs in the Alps at lower elevations were characterized by a typical crenal biocoenosis: the lowest springs situated between 500 and $1600 \mathrm{~m}$ a.s.1. were characterized by crenobiont taxa. Especially many water mite species are restricted to springs and are even adapted to certain spring types (Gerecke and Di Sabatino, 1996). For example, Partnunia steinmanni Walter, 1906 and S. squamosus are restricted to springs below $1400 \mathrm{~m}$ a.s.l. (Gerecke and Martin, 2006). P. squamosa is a typical crenobiont species of forested helocrenes and rheocrenes (Gerecke and Martin, 2006). 


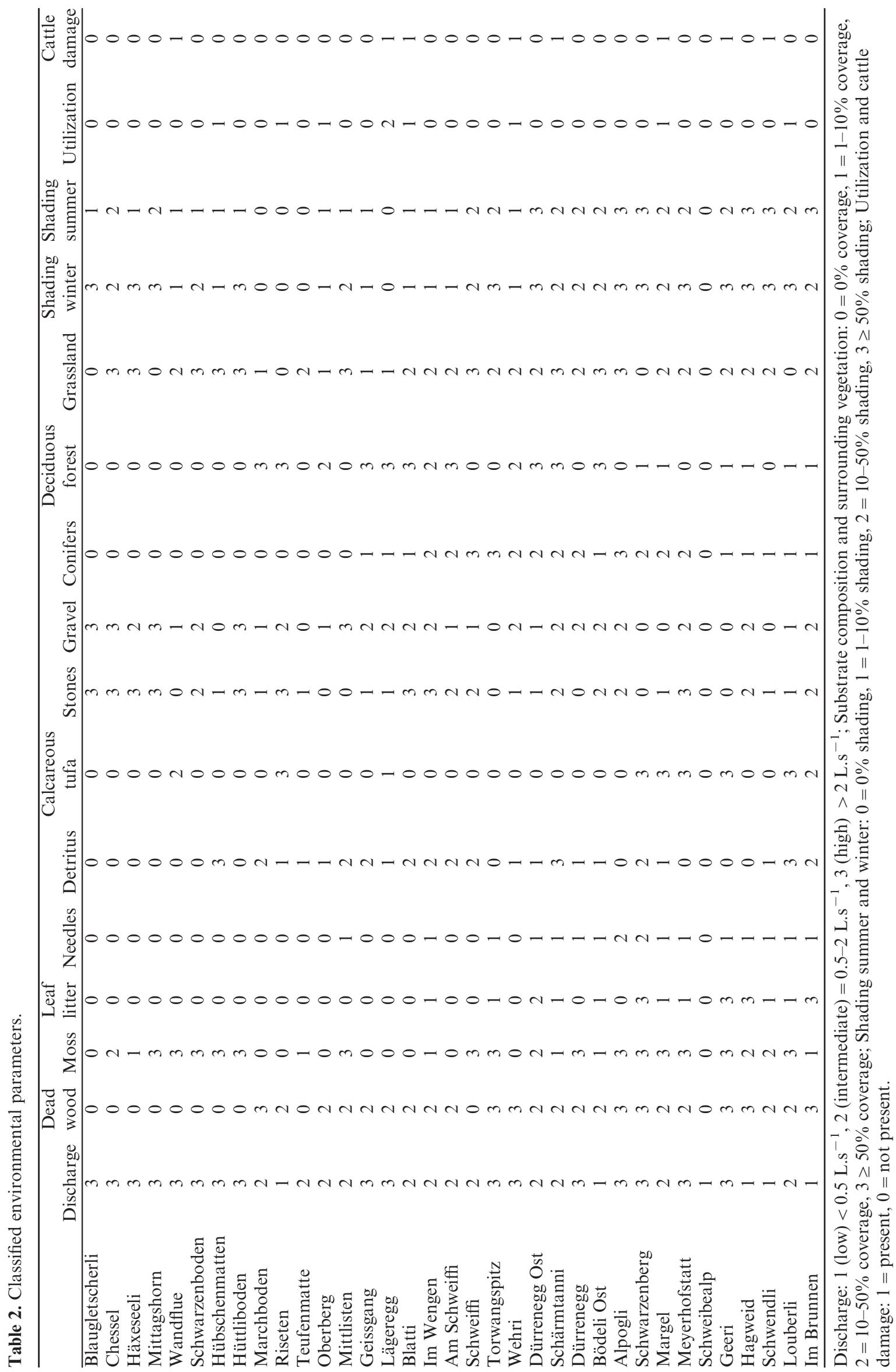




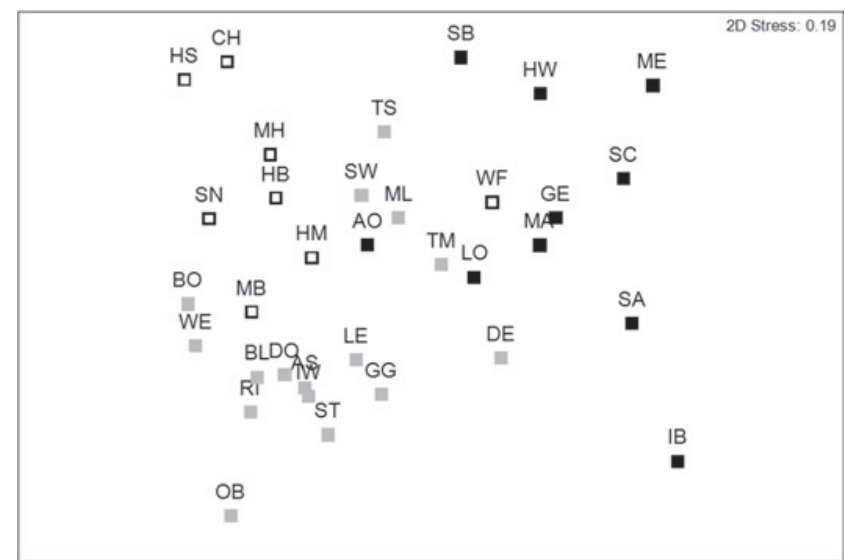

Fig. 2. nMDS of the investigated springs based on the faunistic data. Similarity index: Bray-Curtis; transformation: square root; factor: altitudinal level ( $\boldsymbol{\square}=$ low altitudinal level: $500-1600 \mathrm{~m}$ a.s.l.; $\square=$ intermediate altitudinal level: $1600-1950 \mathrm{~m}$ a.s.l.; $\square=$ high altitudinal level: > $1950 \mathrm{~m}$ a.s.l.).

Springs in the Alps at high elevations were characterized by a typical Alpine rhithral biocoenosis: the springs located above $1900 \mathrm{~m}$ a.s.l. are inhabited by many Alpine species which are adapted to constant low water temperatures. Consorophylax consors, D. biguttatus, Drusus monticola McLachlan, 1876 and R. intermedia are adapted to the crenal and rhithral zones of high Alpine headwaters (Graf et al., 2006). It is known that especially the subfamily Diamesinae of the Chironomidae is adapted to constantly low water temperatures and is the first to colonize glacier-fed brooks (Ward, 1994; Füreder et al., 2001).

The transitional intermediate altitudinal zone was inhabited by typical crenobiont species as well as high Alpine species. Drusus discolor and N. mortoni are typical Alpine species (Bottazzi et al., 2011; Waringer and Graf, 2011). Oxycera morrisii, B. vallata and B. pullata are not limited to the Alps, but can be considered as crenophile or even crenobiont species (Rozkosny, 2000; Waringer and Graf, 2011).

The water temperatures of the investigated springs decreased with increasing altitude as it has been shown previously, for instance, for springs in the Swiss National Park (Robinson et al., 2008) and the Adamello-Brenta Natural Park (Cantonati, 1998). At the intermediate altitude (1600-1950 $\mathrm{m}$ a.s.1.) the springs exhibited a greater heterogeneity of water temperature than those at lower and higher altitudes. This is probably due to the patchy structure of the landscape: the springs at the intermediate level are located around the treeline and therefore some springs are situated in dense forest, whereas others emerge on open countryside and are influenced by solar radiation to a higher degree.

Water temperature is one of the factors which strongly influences the species composition in freshwater ecosystems in general (e.g., Jacobsen et al., 1997; Jacobsen, 2003). For springs, the water temperature has been identified as an important environmental variable explaining the composition of species assemblages both on the small (Bottazzi et al., 2011) and large spatial scale (Gathmann et al., 2009; Ilmonen et al., 2009). The results of our study revealed a strong temperature dependence of species assemblages. Water temperature mainly determined the faunal transition along the altitudinal gradient, from crenobiont species at low altitudes to Alpine, coldwater-adapted species at higher altitudes. These also occurred in the rhithral reaches of high Alpine streams. Crenobionts are confined to springs for a number of reasons, such as habitat stability (van der Kamp, 1995), competition (Fischer, 1996; Wagner et al., 1998) and substrate availability (Hahn, 2000; Ilmonen and Paasivirta, 2005). We therefore conclude that the adaptation to low water temperatures is not the main reason for crenobiosis, i.e., the restriction of occurrence in springs.

We recorded a strong influence of the presence of moss and stones on the species assemblages. Moss is

Table 3. Summary of CCA eigenvalues, cumulative percentage of variance explained on the first four canonical axes, significance of all canonical axes and significant environmental variables identified by a forward selection of the explanatory variables.

\begin{tabular}{lcrr}
\hline & Axis 1 & Axis 2 & Axis 3 \\
\hline Eigenvalue & 0.37 & 0.27 & 0.21 \\
Species environment correlation & 0.98 & 0.98 & 0.99 \\
Cumulative percentage of variance & & 17.36 & 23.14 \\
$\quad$ Explained variation (cumulative) & 10.04 & 24.15 & 32.2 \\
Explained fitted variation (cumulative) & 13.96 & & 28.44 \\
& Fratio & & 39.57 \\
Significance of all canonical axes & $1.4^{* *}$ & & \\
Significant environmental variables & & & \\
Altitude & $2.6^{* *}$ & & \\
Moss & $2.3^{* *}$ & $1.7^{*}$ & \\
Temperature & $1.5^{*}$ & & \\
Stones & $1.6^{*}$ & & \\
Forestation & $1.4^{*}$ & & \\
Number of plants & $1.4^{*}$ & & \\
Calcareous tufa & $1.5^{*}$ & & \\
Ammonia & & & \\
\hline
\end{tabular}

$* P<0.05 ; * * P<0.005$. 
(a)

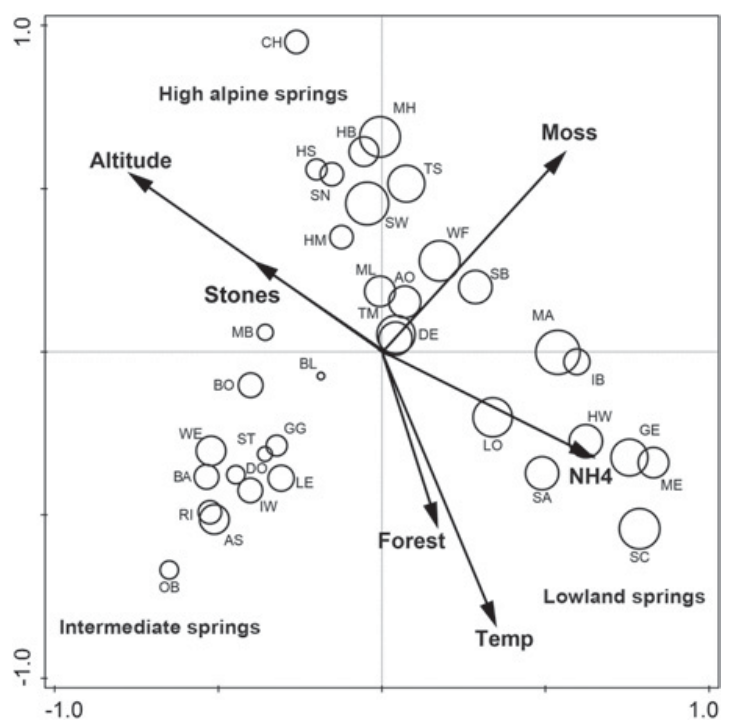

(b)

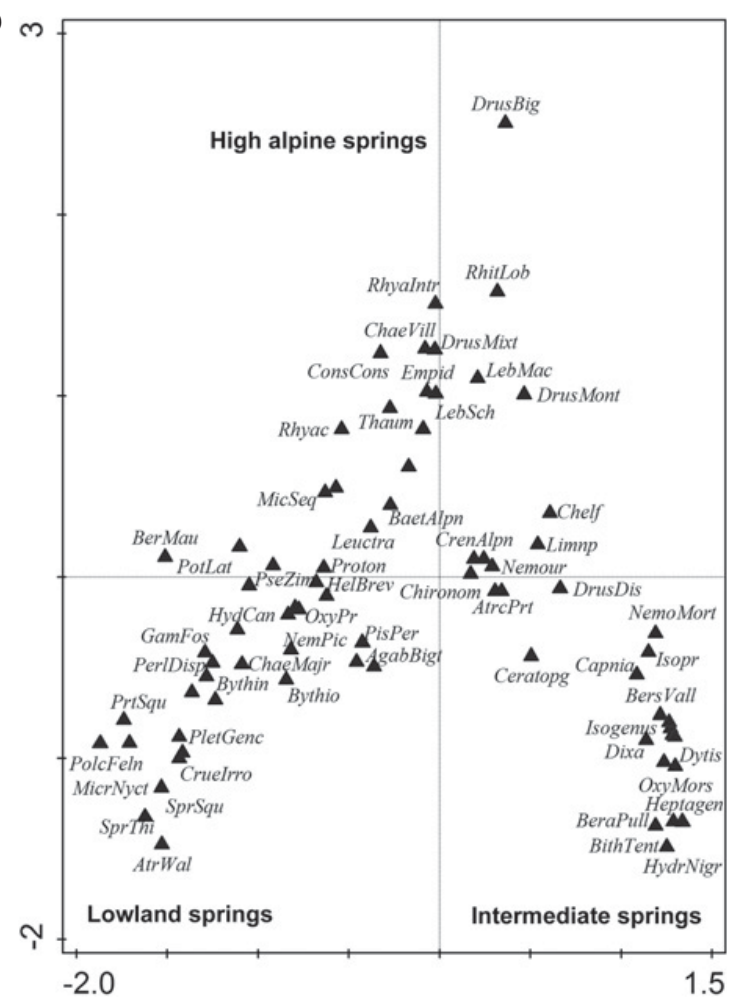

Fig. 3. a, b: Ordination of (a) 35 sites and (b) 108 taxa by a CCA. The environmental variables with the highest explanatory power in the model are indicated by arrows. The size of the circles (a) displays the number of taxa present. A few taxa near the center with low explanatory power, and taxa with single occurrences, have been omitted.

an important factor, which positively influences species richness, functioning as a food source and habitat for example for the caddisfly $C$. irrorata (Ilmonen and Paasivirta, 2005) and for many water mites (Gerecke and Di Sabatino, 1996) in springs. The surface of stones is colonized by diatoms, which are subsequently consumed by scrapers, which dominate at high altitudes (Füreder et al., 2001). Moreover, the CCA revealed a significant influence of the degree of forestation on the composition of the species assemblages. A significantly higher number of vascular plants were found around the springs at the lower altitudes. This leads to a higher input of allochthonous coarse particulate organic matter (CPOM) into the springs, which is especially important for shredders such as G. fossarum (e.g., Simcic and Brancelj, 2006). Indeed, this very important species for the food web of headwaters (Dangles et al., 2004), providing fine particulate organic matter (FPOM) for gathering collectors and filtering collectors, was only present in this study in lower springs situated in a beech forest. Another reason for the absence of $G$. fossarum may be found in the last glaciation: the central Alps still have to be recolonized by amphipods (Cantonati et al., 2006).

Studies predict that montane regions will be affected more strongly by climatic changes than the lowlands (e.g., Bush et al., 2012; Perroud and Bader, 2013; CH2014Impacts, 2014). Range shifts have already been shown for freshwater species (e.g., Vittoz et al., 2013). However, adaptation via range shifts is constrained by catchment boundaries and the dispersal capabilities of the single species (Bush et al., 2012). We conclude that an upwards migration of spring species in the Alps will potentially be possible for species in low altitudinal springs. An upwards migration is, however, not possible for species already living in the highest springs (i.e., summit trap phenomenon (Thuiller et al., 2005; Bässler et al., 2010)). They are at risk of going extinct in the future (Vittoz et al., 2013).

Conductivity decreased with increasing altitude. Changes in conductivity may indicate a changing ratio of ground water, snow melt and glacial meltwater contribution to stream flow (Brown et al., 2003; Hannah et al., 2007), with increasing contributions of meltwater with increasing altitude. High meltwater contributions lead to a decrease of the $\alpha$-diversity (Brown et al., 2007). For high altitudes we can conclude that a decreased contribution of snow and glacial meltwater will increase the $\alpha$-diversity (Brown et al., 2007). The $\beta$-diversity will decrease due to the lower habitat heterogeneity caused by the recession of extreme habitats (Brown et al., 2007; Jacobsen and Dangles, 2012). Springs at intermediate altitudes around the treeline exhibited the lowest $\beta$-diversity. This may be caused by the vertical dispersal of taxa from higher and lower springs, i.e., crenobiont and alpine rhithral species. Those springs may be additionally affected by land use changes. Forest expansion is mainly driven by the abandonment of grasslands in the Alps (Guidi et al., 2014). In our study area the patchy open land structures are becoming visibly overgrown mostly by Alnus viridis (Fabian Wigger, personal observation). This could further diminish the $\beta$-diversity, as the reduced landscape patchiness could reduce the spring habitat diversity and lead to a standardization of the faunistic assemblages. It is unclear how Alpine freshwaters will exactly respond to the proceeding global change. Based on the current state of research it can be assumed that climatic changes will have severe impacts on the spring fauna at all altitudinal levels. 


\section{Conclusions}

This is one of the first studies investigating the distribution pattern of macroinvertebrate assemblages in springs along an altitudinal gradient. The composition of the marcoinvertebrate assemblages clearly changed along the altitudinal gradient; we found characteristic species assemblages at each altitudinal level, with the crenobiont species occurring in the lowest springs, Alpine species occurring in the highest springs and both crenobiont and Alpine species occurring in the springs at the intermediate altitudes. Furthermore, we were able to show that the water temperature has a large influence on the fauna composition of the springs along an altitudinal gradient. Although we have been able to shed some light into the current composition of macroinvertebrate assemblages of springs along an altitudinal gradient, it is not clear what effect global change will have. The current situation is complex and detailed field research is still necessary to understand the functioning of Alpine spring ecosystems.

\section{Supplementary material $\mathbf{1 a}, \mathbf{1 b}, \mathbf{1 c}$}

List of presence $(+)$ and absence $(-)$ of the 108 taxa at each investigated site.

Acknowledgements. The Freiwillige Akademische Gesellschaft of the University of Basel, the Wolfermann-Nägeli-Stiftung and Coca-Cola HBC Schweiz AG helped with some financial support. We would like to thank Dr Peter Martin for determining the water mites and Dr Michel Brancucci for determining the water beetles. Thanks to Dr C. Clarke for proofreading our manuscript. Thanks are also owing to some students who helped with part of the field work. We would also like to thank the farmers, especially family Grossmann, for their help and collaboration.

\section{References}

Altermatt F., Alther R., Fišer C., Jokela J., Konec M., Küry D., Mächler E., Stucki P. and Westram A., 2014. Diversity and distribution of freshwater amphipod species in Switzerland (Crustacea: Amphipoda). PLoS ONE 9, e110328. doi: 10.1371/journal.pone.0110328

Aubert J., 1959. Plecoptera. Insecta Helvetica, Imprimerie La Concorde, Lausanne, 139 p.

Bässler C., Müller J., Hothorn T., Kneib T., Badeck F. and Dziock F., 2010. Estimation of the extinction risk for highmontane species as a consequence of global warming and assessment of their suitability as cross-taxon indicators. Ecol. Indic., 10, 341-352.

Bottazzi E., Bruno E.M.C., Pieri V., Di Sabatino A., Silveri L., Carolli M. and Rosetti G., 2011. Spatial and seasonal distribution of invertebrates in Northern Apennine rheocrene springs. J. Limnol., 70, 77-92.

Brown L.E., Hannah D.M. and Milner A.M., 2003. Alpine stream habitat classification: an alternative approach incorporating the role of dynamic water source contributions. Arct. Antarc., Alp. Res., 35, 313-322.

Brown L.E., Hannah D.M. and Milner A.M., 2007. Vulnerability of alpine stream biodiversity to shrinking glaciers and snowpacks. Glob. Chang. Biol., 13, 958-966.

Burgherr P. and Ward J.V., 2001. Longitudinal and seasonal distribution patterns of the benthic fauna of an alpine glacial stream (Val Roseg, Swiss Alps). Freshw. Biol., 46, 1705-1721.

Bush A., Nipperess D., Turak E. and Hughes L., 2012. Determining vulnerability of stream communities to climate change at the landscape scale. Freshw. Biol., 57, 1689-1701.

Cantonati M., 1998. Le sorgenti del Parco Adamello-Brenta. Parco Documenti, 11, Parco 90 Adamello-Brenta, Strembo (Trento), $177 \mathrm{p}$.

Cantonati M. and Ortler K., 1998. Using spring biota of pristine mountain areas for long term monitoring. Hydrology, Water Resources and Ecology in Headwaters (Proc. of the Headwater'98 Conf. held at Merano/Meran, Italy, April 1998). IAHS Publ., 248, 379-385.

Cantonati M., Gerecke R. and Bertuzzi E., 2006. Springs of the Alps - sensitive ecosystems to environmental change: from biodiversity assessments to long-term studies. Hydrobiologia, 562, 59-96.

CH2014-Impacts, 2014. Towards Quantitative Scenarios of Climate Change Impacts in Switzerland, herausgegeben von OCCR, FOEN, MeteoSwiss, C2SM, Agroscope und ProClim, Bern, Schweiz, 136 p.

Clarke K.R. and Gorley R.N., 2006. PRIMER v6: User Manual/ Tutorial, PRIMER-E, Plymouth.

Dangles O., Gessner M.O., Guérold F. and Chauvet E., 2004. Impacts of stream acidification on litter breakdown: implications for assessing ecosystem functioning. J. Appl. Ecol., 41, 365-378.

Daufresne M., Bady P. and Fruget J.F., 2007. Impacts of global changes and extreme hydroclimatic events on macroinvertebrate community structures in the French Rhone River. Oecologia, 151, 544-559.

Fischer J., 1996. Kaltstenothermie - einziger Schlüssel zum Verständnis der Krenobionten? Crunoecia, 5, 91-96.

Füreder L., Schütz C., Wallinger M. and Burger R., 2001. Physico-chemistry and aquatic insects of a glacier-fed and a spring-fed alpine stream. Freshw. Biol., 46, 1673-1690.

Gathmann F.O., Manne L.L. and Williams D.D., 2009. Spatial patterns in insect community composition in coldwater springs. Aquat. Ecol., 43, 501-512.

Gerecke R. and Di Sabatino A., 1996. Water mites (Acari, Hydrachnellae) and spring typology in Sicily. Crunoecia, 5, 35-42.

Gerecke R. and Franz H., 2006. Quellen im Nationalpark Berchtesgaden. Lebensgemeinschaften als Indikatoren des Klimawandels, Forschungsbericht 51, Berchtesgaden, 272 p.

Gerecke R. and Martin P., 2006. Spinnentiere: Milben (Chelicerata: Acari). In: Gerecke R. and Franz H. (eds.), Quellen im Nationalpark Berchtesgaden, Lebensgemeinschaften als Indikatoren des Klimawandels, Nationalpark Berchtesgaden, Forschungsbericht 51, Berchtesgaden, 122-148.

Glöer P., 2002. Die Süsswassergastropoden Nord- und Mitteleuropas. Die Tierwelt Deutschlands 73, ConchBooks, Hackenheim, 327 p. 
Graf W., Weinzierl A. and De Pietro R., 2006. Köcherfliegen (Trichoptera). In: Gerecke R. and Franz H. (eds.), Quellen im Nationalpark Berchtesgaden, Lebensgemeinschaften als Indikatoren des Klimawandels, Nationalpark Berchtesgaden, Forschungsbericht 51, Berchtesgaden, 165-170.

Guidi C., Magid J., Rodeghiero M., Gianelle D. and Vesterdal L., 2014. Effects of forest expansion on mountain grassland: changes within soil organic carbon fractions. Plant Soil, 385, 373-387.

Hahn H. J., 2000. Studies on classifying of undisturbed spring in Southwestern Germany by macrobenthic communities. Limnologica, 30, 247-259.

Hammer Ø., 2011. PAST: Paleontological statistics software package for education and data analysis, version 2.09. Oslo, $214 \mathrm{p}$.

Hannah D.M., Brown L.E., Milner A.M., Gurnell A.M., McGregor G.R., Petts G.E., Smith B.P.G. and Snook D.L., 2007. Integrating climate-hydrology-ecology for alpine river systems. Aquat. Conserv.: Mar. Freshw. Ecosyst., 17, 636-656.

Henriques-Olivera A.L. and Nessimian J.L., 2010. Aquatic macroinvertebrate diversity and composition in streams along an altitudinal gradient in Southeastern Brazil. Biota Neotrop., 10, 115-128.

Hering D., Schmidt-Kloiber A., Murphy J., Lücke S., ZamoraMunoz C., López-Rodríguez M.J. and Graf W., 2009. Potential impact of climate change on aquatic insects: a sensitivity analysis for European caddisflies (Trichoptera) based on distribution patterns and ecological preferences. Aquat. Sci., 71, 3-14.

Hotzy R. and Römheld J., 2008. Aktionsprogramm Quellen in Bayern - Teil 2: Quellerfassung und-Bewertung, Bayerisches Landesamt für Umwelt, Augsburg, 72 p.

Ilmonen J. and Paasivirta L., 2005. Benthic macrocrustacean and insect assemblages in relation to spring habitat characteristics: patterns in abundance and diversity. Hydrobiologia, 533, 99-113.

Ilmonen J., Paasivirta L., Virtanen R. and Muotka T., 2009. Regional and local drivers of macroinvertebrate assemblages in boreal springs. J. Biogeogr., 36, 822-834.

Jacobsen D., 2003. Altitudinal changes in diversity of macroinvertebrates from small streams in the Ecuadorian Andes. Arch. Hydrobiol., 158, 145-167.

Jacobsen D. and Dangles O., 2012. Environmental harshness and global richness patterns in glacier -fed streams. Glob. Ecol. Biogeogr., 26, 647-656.

Jacobsen D., Schultz R. and Encalada A., 1997. Structure and diversity of stream invertebrate assemblages: the influence of temperature with altitude and latitude. Freshw. Biol., 38, 247-261.

Khamis K., Hannah D.M., Clarvis M.H., Brown L.E., Castella E. and Milner A.M., 2013. Alpine aquatic ecosystem conservation policy in a changing climate. Environ. Sci. Policy, 43, 39-55.

Lassen P. and Savoia S., 2005. Ecoregion conservation plan for the Alps, WWF European Alpine Programme, Bellinzona, $63 \mathrm{p}$.

Lauber K. and Wagner G., 2001. Flora Helvetica. Haupt Verlag, Bern, $1614 \mathrm{p}$.

Lubini V., Knispel S. and Vincon G., 2012. Die Steinfliegen der Schweiz: Bestimmung und Verbreitung. Fauna Helvetiva 27, CSCF \& SEG, Neuchatel, 270 p.
Obertegger U., Thaler B. and Flaim G., 2010. Rotifer species richness along an altitudinal gradient in the Alps. Glob. Ecol. Biogeogr., 19, 895-904.

Perroud M. and Bader S., 2013. Klimaänderung in der Schweiz. Indikatoren zu Ursachen, Auswirkungen, Massnahmen. Umwelt-Zustand Nr. 1308, Bundesamt für Umwelt, Bern und Bundesamt für Meteorologie und Klimatologie, Zürich, $86 \mathrm{p}$.

Robinson C.T., Schmid D., Svoboda M. and Bernasconi S.M., 2008. Functional measures and food webs of high elevation springs in the Swiss alps. Aquat. Sci., 70, 432-445.

Rozkošný R. 2000. Insecta: Diptera: Stratiomyidae. In: Schwoerbel, J. and Zwick P. (eds.), Süßwasserfauna von Mitteleuropa, Spektrum Akademischer Verlag, Heidelberg, 21, 18, 1-110.

Sambugar B., Dessi G., Sapelza A., Stenico A., Thaler B. and Veneri A., 2006. Südtiroler Quellfauna. Autonome Provinz Bozen, $365 \mathrm{p}$.

Schmedtje U. and Kohmann F. 1988. Bestimmungschlüssel für die Saprobier-DIN-Arten (Makroorganismen), Bayrisches Landesamt für Wasserwirtschaft, München, 274 p.

Simcic T. and Brancelj A., 2006. Effects of $\mathrm{pH}$ on electron transport system (ETS) activity and oxygen consumption in Gammarus fossarum, Asellus aquaticus and Niphargus sphagnicolus. Freshw. Biol. 51, 686-694.

Studemann D., Landolt P., Sartori M., Hefti D. and Tomka I., 1992. Ephemeroptera. Insecta Helvetica, Imprimerie Mauron + Tinguely \& Lachat SA, Fribourg, 174 p.

Tachet H., 2000. Invertébrés d'eau douce, CNRS editions, Paris, $588 \mathrm{p}$.

Taubmann J., Theissinger K., Feldheim K.A., Laube I., Graf W., Haase P. and Pauls S.U., 2011. Modelling range shifts and assessing genetic diversity distribution of the montane aquatic mayfly Ameletus inopinatus in Europe under climate change scenarios. Conserv. Genet., 12, 503-515.

ter Braak C.J.F. and Smilauer P., 1998. CANOCO Reference Manual and User's Guide to Canoco for Windows: Software for Canonical Community Ordination (Version 5), Microcomputer Power, Ithaca, New York, 496 p.

Thuiller W., Lavorel S., Araujo M.B., Sykes M.T. and Prentice I.C., 2005. Climate change threats to plant diversity in Europe. Proc. Natl. Acad. Sci. U.S.A., 102, 8245-8250.

Van der Kamp G., 1995. The hydrogeology of springs in relation to the biodiversity of spring fauna: a review. J. Kansas Entomol. Soc., 4-17.

Vittoz P., Cherix D., Gonseth Y., Lubini V., Magginie R., Zbinden N. and Zumbach S., 2013. Climate change impacts on biodiversity in Switzerland: A review. J. Nat. Conserv., 21, 154-162.

Von Fumetti S., Nagel P., Scheifhacken N. and Baltes B., 2006. Factors governing macrozoobenthic assemblages in perennial springs in north-western Switzerland. Hydrobiologia, $568,467-475$.

Von Fumetti S., Nagel P. and Baltes B., 2007. Where a springhead becomes a springbrook - a regional zonation of springs. Fund. Appl. Limnol., 169, 37-48.

Wagner, R., Fischer J. and Schnabel S., 1998. The Dipteran community of Central European springs: a summary. In: Botosaneanu L. (ed.), Studies in Crenobiology, The Biology 
of Springs and Springbrooks, Backhuys, Leiden, pp. 157-166.

Ward L.V., 1994. Ecology of alpine streams. Freshw. Biol., 32, 277-294.

Waringer J. and Graf W., 2011. Atlas der mitteleuropäischen Köcherfliegenlarven, Erik Mauch Verlag, Dinkelscherben, 469 p.
Woodward G., Perkins D.M. and Brown L.E., 2010. Climate change and freshwater ecosystems: impacts across multiple levels of organization. Phil. Trans. R. Soc., 365, 2093-2106.

Zollhöfer J.M., 1997. Quellen die unbekannten Biotope: erfassen, bewerten, schützen, Bristol-Schriftenreihe, Zürich, $153 \mathrm{p}$. 